\title{
E-government and E-governance: Various or Multifarious Concepts
}

\section{Vepkhvia Grigalashvili}

Assistant Professor; Faculty of Social Science, Education and Humanities; International Black Sea University; Tbilisi, Georgia

DOI - http://doi.org/10.37502/IJSMR.2022.5111

\begin{abstract}
E-government and E-governance (as terms and as concepts) are often treated as synonymous and used interchangeably in the academic literature or formal documents. There is no universally accepted definition of both terms / or abstractions. Such conceptual uncertainty has a negative impact on the development of digital democracy. The research objective of this article is to provide a deeper understanding of e-government and e-governance concepts through empirical studies and scatter the existing ambiguity in differences between these two concepts as this variety is not just questions of academic nuance. Based on a comparative analysis of e-government and e-governance definitions and conceptual meanings, this article offers an approach according to which e-government and e-governance represents two closely related and co-existing various concepts.
\end{abstract}

Keywords: Electronic Government; Electronic Governance; Digital Governance; Digital Democracy; Digital Government.

\section{Introduction}

Numerous factors have impacted and contributed to the growth and institutionalisation of social phenomenon digital governance and its particular institutional components as followings e-government and e-governance. Generally, it is attributable to the need to respond to the particular pressures or challenges (including increasing budgetary pressures, rising expectations, growing inequality and declining public trust, e-commerce and etc.) facing governments in developed and developing countries (Hannah, 2010). The growth of egovernment in developing countries has mainly been driven by external forces, notably the international financial institutions (such as the World Bank and the IMF) (infoDev, 2002; OECD, 2003; Heeks, 2002) and internal issues, primarily the demands for public safety and security within national borders have necessitated re-thinking on the role of digital facilities in the delivery of services to the public.

Notwithstanding, a unified conceptual or grand vision, regarding e-government and egovernance, has not been achieved yet and the conceptual boundaries of both phenomenon are unclear. Moreover, it is uncertain whether e-government includes both internal and external aspects of public service, such as governance.

Some scholars contend that e-government constitutes only a subset (though a major one) of e- 
governance - e-governance is a broader concept and includes the use of ICT by government and civil society to promote greater participation of citizens in the governance of political institutions, e.g., use of the Internet by politicians and political parties to elicit views from their constituencies in an efficient manner, or the publicizing of views by civil society organizations which are in conflict with the ruling powers (Howard, 2001; Bannister and Walsh, 2002).

Cook et al. (2002) and Snellen (2006) think that e-government encompasses all aspects of public service delivery and governance. Accordingly, e-governance is a much broader concept, as it encompasses the use of information communication technologies (ICT) in a state's institutional arrangements, decision- making processes, and the implementation of all kinds of changes in relationships between the government and the public; e-government, on the other hand, seems to be essentially a subset of e-governance. Pina eí/í/ (2006) suggests that egovernance includes e-government (UNESCO 2011).

According to Sheridan and Riley (2006), e-governance is a broader concept that deals with the whole spectrum of the relationship and networks within government regarding the usage and application of ICTs whereas e-government is limited to the development of online services).

Other scholars, such as Anttiroik (2007) describes e-government and e-governance as two completely different concepts. E-governance is a broader term comprising a range of relationships and networks in the government, related to the use and application of ICT. Egovernment is a more restricted area associated with the development of direct (online) services to citizens, paying greater attention to such government services as e-taxes, e-education or ehealth. E-governance is a concept that defines the impact of technology on governance practices, the relationship between the government and the public, NGOs and private sector entities. E-governance covers the entire range of government steps develop and administrate, and to ensure successful implementation of e-government services offered to the public. The original idea of e-government has been attributed to the public's need for access to the government decisions and documents via electronic means, later appeared the need of public electronic services, and finally - a search of opportunities to participate in the decision making process, to consult with the government institutions.

Roy (2007) considers that a distinction must be made between e-governance and e-government, with the former referring to the process of sharing and reorganizing of power across all stakeholders and the citizenry while the latter is more focused on public service delivery. It is possible to perceive the concept of e-government and e-governance very differently depending on their focus (Yildiz, 2007).

Existing conceptual uncertainty is illustrated by Yildiz (2007). According to which some digital interaction tools $(\mathrm{G} 2 \mathrm{G}, \mathrm{G} 2 \mathrm{C}, \mathrm{G} 2 \mathrm{~B}, \mathrm{G} 2 \mathrm{SC}, \mathrm{C} 2 \mathrm{C})$ is discussed as of e-government or egovernance or e-administration: Government -to-Government $(\mathrm{G} 2 \mathrm{G})$ - belongs to definition of e-administration (example: establishing and using a common data warehouse; Government-toCitizen (G2C) - belongs to definition of e-government (example: government organization Web Sites, E-mail communication between citizens and government officials); Governmentto-Business (G2B) - belongs to definition of e-government, e-commerce, e--collaboration) (example: Posting government bids on the Web, e-procurement, e-partnerships); Governmentto-Civil Society Organisations (G2SC) - belongs to definition of e-governance (example: 
electronic communications and coordination efforts after disaster); Citizen-to-Citizen (C2C) belongs to definition of e-governance (example: electronic discussion groups on civic issues).

It is clear that considerable confusion exists in explaining e-government and e-governance domains. Follow this, we attempt to resolve such ambiguity and come up with non-overlapping understanding of both phenomenon by reviewing and analyzing existing conceptual framework that provides details and establishes relationships of key variables or similarities.

\section{Results and Discussions}

\subsection{E-government: Conceptual Visions}

There is not any universally accepted definition of the e-government concept (Halchin, 2004).

Examination of official documents, analytical or scientific literature shows that "egovernment" continues to evolve, depending on the context. As Homburg (2008) outlines that e-government is hence multifaceted and has been implemented in a variety of forms and shapes, further complicating the process of trying to determine a single, universal meaning.

E-government, characterised as a multifaced concept (Tab. 1), has a different meaning to different constituents (Gauld and Goldfinch, 2006): for politicians e-government plays role an engine for reform and to meet the aspirations of new public management; for the general public, e-government is viewed as a source of greater information and influence on government; for the bureaucrats, e-government is viewed as a managerial tool to improve their service delivery.

E-government has been discussed in different aspects: in the context of technology (Zhiyuan, 2002); from a service delivery perspective (Norris and Moon 2005); from a citizen-centric perspective (Roy, 2007); from a functional perspective (Selfert and Petersen, 2002); from a social fabric perspective (Brown, 2005); and from a radical change perspective (Kraemer and King 2008).

Table 1: Definitions/Conceptual Meanings of Term E-government 


\begin{tabular}{|c|c|}
\hline United Nations & $\begin{array}{l}\text { "E-government has been employed to mean everything from 'online } \\
\text { government services" to "exchange of information and services } \\
\text { electronically with citizens, businesses, and other arms of government. } \\
\text { E-government can thus be defined as the use of ICTs to more } \\
\text { effectively and efficiently deliver government services to citizens and } \\
\text { businesses. It is the application of ICT in government operations, } \\
\text { achieving public ends by digital means. The underlying principle of e- } \\
\text { government, supported by an effective e-governance institutional } \\
\text { framework, is to improve the internal workings of the public sector by } \\
\text { reducing financial costs and transaction times so as to better integrate } \\
\text { work flows and processes and enable effective resource utilization } \\
\text { across the various public sector agencies aiming for sustainable } \\
\text { solutions. Through innovation and e-government, governments around } \\
\text { the world can be more efficient, provide better services, respond to the } \\
\text { demands of citizens for transparency and accountability, be more } \\
\text { inclusive and thus restore the trust of citizens in their governments." }\end{array}$ \\
\hline $\begin{array}{l}\text { United Nations } \\
\text { (AOEMA report) }\end{array}$ & $\begin{array}{l}\text { "E-government is defined as utilizing the Internet and the world-wide- } \\
\text { web for delivering government information and services to citizens." }\end{array}$ \\
\hline World Bank & $\begin{array}{l}\text { "E-Government" refers to the use by government agencies of } \\
\text { information technologies (such as Wide Area Networks, the Internet, } \\
\text { and mobile computing) that have the ability to transform relations with } \\
\text { citizens, businesses, and other arms of government. These technologies } \\
\text { can serve a variety of different ends: better delivery of government } \\
\text { services to citizens, improved interactions with business and industry, } \\
\text { citizen empowerment through access to information, or more efficient } \\
\text { government management. The resulting benefits can be less } \\
\text { corruption, increased transparency, greater convenience, revenue } \\
\text { growth, and/or cost reductions." }\end{array}$ \\
\hline EU Parliament & $\begin{array}{l}\text { "e-Government refers to efforts by public authorities to use } \\
\text { information and communication technologies (ICTs) to improve public } \\
\text { services and increase democratic participation. E-Government aims to } \\
\text { improve government efficiency through the reduced cost of electronic } \\
\text { information management and communications, the reorganization of } \\
\text { government agencies and the reduction of administrative silos of } \\
\text { information." }\end{array}$ \\
\hline OECD & $\begin{array}{l}\text { "The term "e-government" focuses on the use of new information and } \\
\text { communication technologies (ICTs) by governments as applied to the } \\
\text { full range of government functions. In particular, the networking } \\
\text { potential offered by the Internet and related technologies has the } \\
\text { potential to transform the structures and operation of government." }\end{array}$ \\
\hline
\end{tabular}




\begin{tabular}{|c|c|}
\hline $\begin{array}{l}\text { Working Group on } \\
\text { E-government in the } \\
\text { Developing World }\end{array}$ & $\begin{array}{l}\text { "E-government is the use of information and communication } \\
\text { technologies (ICTs) to promote more efficient and effective } \\
\text { government, facilitate more accessible government services, allow } \\
\text { greater public access to information, and make government more } \\
\text { accountable to citizens. E-government might involve delivering } \\
\text { services via the Internet, telephone, community centers (self-service or } \\
\text { facilitated by others), wireless devices or other communications } \\
\text { systems." }\end{array}$ \\
\hline $\begin{array}{l}\text { United States of } \\
\text { America }\end{array}$ & $\begin{array}{l}\text {...'electronic Government' means the use by the Government of web- } \\
\text { based Internet applications and other information technologies, } \\
\text { combined with processes that implement these technologies, to - "(A) } \\
\text { enhance the access to and delivery of Government information and } \\
\text { services to the public, other agencies, and other Government entities; } \\
\text { or "(B) bring about improvements in Government operations that may } \\
\text { include effectiveness, efficiency, service quality, or transformation; } \\
\text { information and services to the public, other agencies, and other } \\
\text { Government entities." }\end{array}$ \\
\hline IGI Global & $\begin{array}{l}\text { "This term can be defined as the use of ICTs to more effectively and } \\
\text { efficiently deliver government services to citizens and businesses. It is } \\
\text { the application of ICT in government operations, achieving public } \\
\text { ends by digital means. The use of or application of information } \\
\text { technologies (such as Internet and intranet systems) to government } \\
\text { activities and processes in order to facilitate the flow of information } \\
\text { from government to its citizens, from citizens to government and } \\
\text { within government. Refers to the use of new information and } \\
\text { communication technologies (ICTs) by governments as applied to the } \\
\text { full range of government functions." }\end{array}$ \\
\hline $\begin{array}{l}\text { Gartner Group } \\
(2000)\end{array}$ & $\begin{array}{l}\text {..."the continuous optimization of service delivery, constituency } \\
\text { participation, and governance by transforming internal and external } \\
\text { relationships through technology, the Internet and new media." }\end{array}$ \\
\hline $\begin{array}{l}\text { GBDe definition } \\
\text { cited from Bashar, } \\
\text { Rezaul and Grout } \\
\text { (2011) }\end{array}$ & $\begin{array}{l}\text { "Electronic government (hereafter e-Government) refers to a situation } \\
\text { in which administrative, legislative and judicial agencies (including } \\
\text { both central and local governments) digitize their internal and external } \\
\text { operations and utilize networked systems efficiently to realize better } \\
\text { quality in the provision of public services." }\end{array}$ \\
\hline
\end{tabular}




\begin{tabular}{|c|c|}
\hline Key deferences & $\begin{array}{l}\text { "e-Government implies the implementation of information and } \\
\text { communication technology like internet, to improve government } \\
\text { activities and process, with the aim of increasing efficiency, } \\
\text { transparency, and citizen involvement. On the other hand. } \\
\text { e-Government may be defined as the integration of information and } \\
\text { communication technology, in public administration, i.e. to various } \\
\text { government processes, operations, and structures with the purpose of } \\
\text { enhancing transparency, efficiency, accountability and citizen } \\
\text { participation. It facilitates: Greater level of efficiency and effectiveness } \\
\text { in government activities and process. Enhances quality of public } \\
\text { services; Simplifies administrative processes; Improves access to } \\
\text { information; Increases communication between various government } \\
\text { agencies; Strengthen support to public policy; Enables seamless } \\
\text { government." }\end{array}$ \\
\hline $\begin{array}{l}\text { Norris and Moon } \\
(2005)\end{array}$ & $\begin{array}{l}\text { "The electronic provision of information and services by governments, } \\
24 \text { hours a day, } 7 \text { days a week." }\end{array}$ \\
\hline $\begin{array}{l}\text { Kraemer and King, } \\
(2003)\end{array}$ & $\begin{array}{l}\text { "The use of information technology within government to achieve } \\
\text { more efficient operations, better quality of service, and easy public } \\
\text { access to government information and services." }\end{array}$ \\
\hline Brown (2005) & $\begin{array}{l}\text { "The entire range of government roles and activities, shaped by } \\
\text { and making use of information and communications technologies." }\end{array}$ \\
\hline $\begin{array}{l}\text { Cook, Lavigne, } \\
\text { Pagano, Dawes and } \\
\text { Pardo (2002) }\end{array}$ & $\begin{array}{l}\text { "The uses of information technology to support operations, } \\
\text { engage citizens, and provide government services." }\end{array}$ \\
\hline Fang (2002) & $\begin{array}{l}\text {..."is defined e-government as a way for governments to use the most } \\
\text { innovative information and communication technologies, particularly } \\
\text { web-based Internet applications, to provide citizens and businesses } \\
\text { with more convenient access to government information and services, } \\
\text { to improve the quality of the services and to provide greater } \\
\text { opportunities to participate in democratic institutions and processes." }\end{array}$ \\
\hline Fraga (2002) & $\begin{array}{l}\text {.."e-government involves the use of ICTs to support government } \\
\text { operations and provide government services." }\end{array}$ \\
\hline Leitner (2003) & $\begin{array}{l}\text {...'e-government goes even further and aims to fundamentally } \\
\text { transform the production processes in which public services are } \\
\text { generated and delivered, thereby transforming the entire range of } \\
\text { relationships of public bodies with citizens, businesses and other } \\
\text { governments." }\end{array}$ \\
\hline
\end{tabular}

E-government is also perceived differently in connection with its theoretical background. According to Garson (1999), there are four theoretical frameworks within which e-government is conceptualised. The first framework involves the potential of IT in decentralization and democratization. The second normative/ dystopian framework underlines the limitations and 
contradictions of technology. Third, the sociotechnical systems approach emphasizes the continuous and two-way interaction of the technology and the organizational-institutional environment. The fourth framework places e-government within theories of global integration.

\subsection{E-governance: Conceptual Visions}

Just as there are many conceptual views of governance, there are many conceptual approaches of e-governance (Godse and Garg, 2011). Although they do not always run inline, generally egovernance refers to the use of information and communication technologies to transform and support the processes and structures of a governance system. In order to cover the variety of uses and the nuances sufficiently, several definitions / meanings are presented in the (Tab. 2).

Table 2: Definitions / Conceptual Meanings of E-governance

\begin{tabular}{|c|c|}
\hline Authors & Definitions / Conceptual Meanings \\
\hline Council of Europe & $\begin{array}{l}\text { "E-governance is about the use of information technology to raise the } \\
\text { quality of the services governments deliver to citizens and businesses. } \\
\text { It is hoped that it will also reinforce the connection between public } \\
\text { officials and communities thereby leading to a stronger, more } \\
\text { accountable and inclusive democracy." }\end{array}$ \\
\hline UNESCO & $\begin{array}{l}\text { "E-governance is the public sector's use of information and } \\
\text { communication technologies with the aim of improving information } \\
\text { and service delivery, encouraging citizen participation in the decision- } \\
\text { making process and making government more accountable, transparent } \\
\text { and effective. E-governance involves new styles of leadership, new } \\
\text { ways of debating and deciding policy and investment, new ways of } \\
\text { accessing education, new ways of listening to citizens and new ways of } \\
\text { organizing and delivering information and services. E-governance is } \\
\text { generally considered as a wider concept than e-government, since it can } \\
\text { bring about a change in the way citizens relate to governments and to } \\
\text { each other. E-governance can bring forth new concepts of citizenship, } \\
\text { both in terms of citizen needs and responsibilities. Its objective is to } \\
\text { engage, enable and empower the citizen." }\end{array}$ \\
\hline $\begin{array}{l}\text { ÖKTEM, } \\
\text { DEMIRHAN } \\
(2004)\end{array}$ & $\begin{array}{l}\text { "Electronic governance (e-governance) applications are related to both } \\
\text { the usage of technology and citizen participation in politics. } \\
\text { "Electronic" indicates the technological capacities of our age and } \\
\text { "governance" is a new perspective in government paradigm. } \\
\text { Innovations in both technology and perspective create new } \\
\text { understandings for governing such as "governing with people." }\end{array}$ \\
\hline $\begin{array}{l}\text { Bedi, Singh and } \\
\text { Srivastava (2001) } \\
\text { Holmes (2001) } \\
\text { Okot-Uma (2000) }\end{array}$ & $\begin{array}{l}\text {...'meaning 'electronic governance' is using information and } \\
\text { communication technologies (ICTs) at various levels of the government } \\
\text { and the public sector and beyond, for the purpose of enhancing } \\
\text { Governance." }\end{array}$ \\
\hline
\end{tabular}




\begin{tabular}{|c|c|}
\hline $\begin{array}{l}\text { Keohane and Nye } \\
(2000)\end{array}$ & $\begin{array}{l}\text { "Governance implies the processes and institutions, both formal and } \\
\text { informal, that guide and restrain the collective activities of a group. } \\
\text { Government is the subset that acts with authority and creates formal } \\
\text { obligations. Governance need not necessarily be conducted exclusively } \\
\text { by governments. Private firms, associations of firms, nongovernmental } \\
\text { organizations (NGOs), and associations of NGOs all engage in it, often } \\
\text { in association with governmental bodies, to create governance; } \\
\text { sometimes without governmental authority." }\end{array}$ \\
\hline Clift (2003) & $\begin{array}{l}\text { "E-democracy builds on e-governance and focuses on the actions and } \\
\text { innovations enabled by ICTs combined with higher levels of } \\
\text { democratic motivation and intent." }\end{array}$ \\
\hline Backus (2001) & $\begin{array}{l}\text { "E-governance is defined as the, "application of electronic means in (1) } \\
\text { the interaction between government and citizens and government and } \\
\text { businesses, as well as (2) in internal government operations to simplify } \\
\text { and improve democratic, government and business aspects of } \\
\text { Governance." }\end{array}$ \\
\hline IGI Global & $\begin{array}{l}\text { "Electronic Governance is the application of Information and } \\
\text { Communication Technologies (ICTs) for delivering government } \\
\text { services through integration of various stand-alone systems between } \\
\text { Government-to-Citizens (G2C), Government-to-Business (G2B), and } \\
\text { Government-to-Government (G2G) services. It is often linked with } \\
\text { back office processes and interactions within the entire government } \\
\text { framework. Through e-Governance, the government services are made } \\
\text { available to the citizens in a convenient, efficient, and transparent } \\
\text { manner." }\end{array}$ \\
\hline Oakley (2002) & $\begin{array}{l}\text { "A technology mediated service that facilitates a transformation in the } \\
\text { relationship between government and citizen." }\end{array}$ \\
\hline $\begin{array}{l}\text { Riley (2001) cited } \\
\text { by Saxena (2003) }\end{array}$ & $\begin{array}{l}\text { The commitment to utilize appropriate technology for a variety of ends } \\
\text { including greater democracy and fair and efficient services. }\end{array}$ \\
\hline $\begin{array}{l}\text { Palvia and Sharma } \\
\text { (2007) }\end{array}$ & $\begin{array}{l}\text { "Propose a framework for differentiating between e-government and e- } \\
\text { governance. In their model, e-governance is concerned with internally } \\
\text { focused use of ICT ro manage organizational resources and administer } \\
\text { policies and procedures; e-government is outward and citizen directed." }\end{array}$ \\
\hline $\begin{array}{l}\text { Sheridan and Riley } \\
\text { (2010) }\end{array}$ & $\begin{array}{l}\text { ".. . deals with tbe whole spectrum of the relationship and } \\
\text { networks within government regarding the usage and application } \\
\text { oflCTs." }\end{array}$ \\
\hline $\begin{array}{l}\text { Chen and Hsish } \\
\text { (2009) }\end{array}$ & $\begin{array}{l}\text { "The use of ICT to improve the quality of services and governance (cf } \\
\text { UNESCO)." }\end{array}$ \\
\hline $\begin{array}{l}\text { Marche and } \\
\text { McNiven }\end{array}$ & $\begin{array}{l}\text {... " a technology-mediated relationship between citizens and their } \\
\text { governments from the perspective of potential electronic deliberation }\end{array}$ \\
\hline $\begin{array}{l}\text { Dawes (2008) } \\
\text { Potnis (2009) }\end{array}$ & $\begin{array}{l}\text { "ICTs provide interactive communication channels, which are } \\
\text { important in the transformation of the current governing process to a } \\
\text { governing process that is open to the collaboration and deliberation of }\end{array}$ \\
\hline
\end{tabular}




\begin{tabular}{|c|c|}
\hline & $\begin{array}{l}\text { different actors in the processes of service provision and information } \\
\text { delivery." }\end{array}$ \\
\hline $\begin{array}{l}\text { Pina et al., (2007) } \\
\text { Sandoval-Almazan } \\
\text { and Gil-Garcia } \\
(2012)\end{array}$ & $\begin{array}{l}\text { "E-governance refers to the use of ICTs to reach the aims related to } \\
\text { governance. Governance can be explained in terms of its main } \\
\text { components. These components are participation, transparency and } \\
\text { accountability, information and service delivery, and communication } \\
\text { and interaction in governing processes." }\end{array}$ \\
\hline $\begin{array}{l}\text { Lean, Zailani, } \\
\text { Ramayah, and } \\
\text { Fernando (2009) }\end{array}$ & $\begin{array}{l}\text { "E-governance is related to the use of information and communication } \\
\text { technologies in policymaking, legitimating, auditing, accounting of } \\
\text { government application, providing transparency and accountability of }\end{array}$ \\
\hline OECD (2001) & $\begin{array}{l}\text {... "means "preparing for greater and faster interactions with citizens } \\
\text { and ensure better knowledge management." }\end{array}$ \\
\hline Prabha (2004) & $\begin{array}{l}\text { "A form of e-business in governance comprising of process and } \\
\text { structures involved in deliverance of electronic service to the public, } \\
\text { viz. citizens." }\end{array}$ \\
\hline Kettl (2002) & $\begin{array}{l}\text { "The impact [from e-government interactions] on government, public } \\
\text { service and citizens throughout the political process, policy } \\
\text { development, program design and service delivery." }\end{array}$ \\
\hline Oakley (2002) & $\begin{array}{l}\text { "A technology mediated service that facilitates a transformation in the } \\
\text { relationship between government and citizen." }\end{array}$ \\
\hline $\begin{array}{l}\text { Gordon (2002) } \\
\text { Signore et } \\
\text { al.(,2005) }\end{array}$ & $\begin{array}{l}\text {..." defines e-government as the use of ICT to improve the process of } \\
\text { government.In a narrow sense it is sometimes defined as citizen's } \\
\text { services, re-engineering with technology, or procurement over } \\
\text { Internet." }\end{array}$ \\
\hline $\begin{array}{l}\text { Spremić et al. } \\
(2009)\end{array}$ & $\begin{array}{l}\text {..."e-government denotes the use of information technologies } \\
\text { and the Internet for better delivery government services to citizens. It } \\
\text { denotes also a more efficient management and improvement of } \\
\text { interactions between government and citizens." }\end{array}$ \\
\hline $\begin{array}{l}\text { Marthandan and } \\
\text { Tang (2010) }\end{array}$ & $\begin{array}{l}\text {..." interactions between economic, political and social actors. Indeed } \\
\text { e-government allows businesses to transact with each other more } \\
\text { efficiently (B2B) and brings customers closer to businesses (B2C). } \\
\text { Also, e-government enable links between government and citizens } \\
\text { (G2C), government and businesses enterprises (G2B) and interagency } \\
\text { relationships (G2G)." }\end{array}$ \\
\hline $\begin{array}{l}\text { Signore et al. } \\
(2005)\end{array}$ & $\begin{array}{l}\text { "E-governance is a concept larger than the concept of e-government } \\
\text { since it can bring about a change in the way how citizens relate to } \\
\text { government and to each other." }\end{array}$ \\
\hline $\begin{array}{l}\text { Key differences } \\
\text { (2017) }\end{array}$ & $\begin{array}{l}\text { "e-Governance means governing or administering a country/state or } \\
\text { organization, with the help of information and communication } \\
\text { technology. } \\
\text { Electronic governance, shortly known as e-governance refers to the } \\
\text { utilization of information and communication technology (ICT) for }\end{array}$ \\
\hline
\end{tabular}




\begin{tabular}{|l|l|}
\hline & $\begin{array}{l}\text { providing government services, disseminating information, } \\
\text { communication activities, and incorporation of miscellaneous stand } \\
\text { alone system and services between different models, processes and } \\
\text { interaction within the overall structure. } \\
\text { E-governance is a tool, that makes available various government } \\
\text { services to citizens in a convenient way, such as: Better provision of } \\
\text { government services; Improved interaction with different groups; } \\
\text { Citizen empowerment through access to information; Efficient } \\
\text { government management." }\end{array}$ \\
\hline $\begin{array}{l}\text { Margolis and } \\
\text { (2010) }\end{array}$ & $\begin{array}{l}\text {..'e-governance is focused on the democratic processes." } \\
\text { (2009) }\end{array}$ \\
\hline UNESCO (2005) & $\begin{array}{l}\text { "e-governance is the use of information and communication } \\
\text { technologies in public administration in order to improve the } \\
\text { information and public service, encouraging the citizens' participation } \\
\text { accountable, transparent and effective." }\end{array}$ \\
\hline
\end{tabular}

Depending on the particular conditions and governance requirements or activities, Halachmi (2007) suggests five important models of e-governance: (i) The Broadcasting Model of dissemination of useful governance information to have informed citizenry; (ii) The Critical Flow Model of routing information of critical value to the targeted audience; (iii) The Comparative Analysis Model of assimilation of best practices in the field of governance for developing countries to empower their people; (IV) The E-Advocacy/ Mobilisation and Lobbying Model of adding the opinions of virtual communities so that the global civil society can have an impact on global decision-making processes; (v) The Interactive-Service Model of individuals' direct participation in governance processes to bring in greater objectivity and transparency in decision-making processes.

\subsection{E-government and E-governance Terms Components}

The "E" part of both e-government and e-governance stands for the electronic platform or infrastructure that enables and supports the networking of public policy development and deployment (Sheridan and Riley, 2006)

Government is an institutional superstructure that society uses to translate politics into policies and legislation. Governments are specialised institutions that contribute to governance. Governments are bureaucratically organized and constitutionally legitimated. They serve as both the highest forum for policy making within their jurisdictions, and as the final court of appeal within their jurisdictions for dissenters to those policies. Most of the work of governments consists of actually implementing policies through service delivering programs. Individuals and groups assess governmental performance in terms of their own perception. Governments often face the need to rationalize discrepancies amongst people's desires to achieve their own ends (Godse and Garg, 2011). 
Governance is the outcome of the interaction of government, the public service, and citizens throughout the political process, policy development, program design, and service delivery. The institution of government involves a narrower range of considerations than the wider functions of governance. Governance is distinct from government as it concerns longer-term processes rather than immediate decisions. Governance is a set of continuous processes that usually evolve slowly with use unlike government. The governance focuses on processes instead of decisions. Governance takes the larger view of social objectives, so it involves the coordination of efforts rather than the implementation of specific programs. This is the systemic perspective as opposed to a focus on the individual practice, or player, or process. The "bottom line" for governance is outcomes rather than the outputs of government (Godse and Garg, 2011).

\section{Conclusion}

A comparative analysis of e-government and e-governance reveals that discussed concepts have to be considered as two distinct abstractions (Sheridan and Riley, 2010):

(a) E-government is an institutional approach to jurisdictional political operations and a narrower discipline dealing with the development of online services to the citizen, more the e on any particular government service - such as e-tax, e-transportation or e-health, such as not for profits organizations, NGOs or private sector corporate entities.

(b) E-governance is a procedural approach to co-operative administrative relations, i.e. the encompassing of basic and standard procedures within the confines of public administration. It is the latter that acts as the lynchpin that will ensure success of the delivery of e-services. E-governance is a broader topic that deals with the whole spectrum of the relationship and networks within government regarding the usage and application of ICTs. E-governance is a wider concept that defines and assesses the impacts technologies are having on the practice and administration of governments and the relationships between public servants and the wider society, such as dealings with the elected bodies or outside groups. E-governance encompasses a series of necessary steps for government agencies to develop and administer to ensure successful implementation of e-government services to the public at large. The differences between these two important constructs are explored further in this essay.

Based on the results of the study conceptual frameworks of e-government and e-governance are based on following main strategic pillars: e-government is a system whereas e-governance is a functionality, e-government is a one-way communication protocol. On the contrary, egovernance is a two-way communication protocol (Kafle, 2018).

\section{References:}

1) Anttiroiko A.V. (2007). Democratic e-Governance - Basic Concepts, Issues and Future Trends. Digest of

2) Electronic Government Policy and Regulation 30, 83-90, IOS Press

3) Backus, M. (2001) E-Governance and Developing Countries, Introduction and examples, Research Report, No. 3, April 2001 
4) Bannister, F. and Walsh, N. (2002), The virtual public servant: Ireland's public services broker. InformationPolity: The International Journal of Government \& Democracy in the Information Age , 7 (2/3)

5) Bashar M.R., Rezaul K.M., Grout V., (2011), E-Government vs. Ordinary Bureaucratic Government: A Comparative Study

6) Bedi, K., Singh, P.J. \& Srivastava, S. (2001) government net: new governance opportunities for India.New Delhi: Sage

7) Brown, M. M. (2001). The Benefits and Costs of Information Technology Innovations: An Empirical Assessment of a Local Government Agency. Pubic Performance \& Management Review, 24

8) Budd, L., Harris, L. (Red.). (2009). E-governance: managing or governing? New York, NY: Routledge

9) Clift, S. (2003) E-Governance to E-Democracy: Progess in Australia and New Zealand toward InformationAge

Democracy http://www.publicus.net/articles/edempublicnetwork.html

10) Cook, M. E., LaVigne, M. F., Pagano, C. M., Dawes, S. S., and Pardo, T. A. (2002). Making a Case for Local E-Government. Albany, New York: Center for Technology in Government

11) Council of Europe, E-governance, https://www.coe.int/t/dgap/democracy/Activities/GGIS/E-governance/Default_en.asp

12) Davies, R., (2015) European Parliament, e-Government Using technology to improve public services and democratic participation, IN-DEPTH ANALYSIS

13) Dawes, S. S. (2008). The evolution and continuing challenges of e-governance [Special Issue]. Public Administration Review, December, 86-102. doi: 10.1111/j.15406210.2008.00981.x

14) E-Government Act. (2002), https://www.justice.gov/opcl/e-government-act-2002

15) Fang, Z. (2002). E-government in digital era: concept, practice, and development. International Journal of The Computer, The Internet and Management, 10(2)

16) Fraga, E. (2002) "Trends in e-Government: How to Plan, Design, and Measure eGovernment". Government Management Information Sciences (GMIS) Conference, June 17, Santa Fe, New Mexico, U.S.A

17) Howard, M. (2001) E-Government across the globe: How will "e" change government? Government Finance Review, vol. 17, Issue 4

18) Garson, G. D. (1999). Information systems, politics, and government: Leading theoretical perspectives. In G. D.

19) Garson (Ed.), Handbook of public information systems. New York: Marcel Dekker.

20) Gartner Group (2000), Key Issues in E-Government Strategy and Management. Research Notes, Key Issues (23 May 2000)

21) Godse, V. and Garg, A., (2011), From E-government to E-governance, https://www.csisigegov.org/1/2_313.pdf

22) Gordon F.T. (2002). E-government-introduction. ERCIM News n.48

23) Halachmi, A., (2007), E-Government Theory and Practice: The Evidence from Tennessee USA, in Marc Holzer, Mengzhong Zhang, and Keyong Dong, (eds.), 
Frontiers of Public Administration, The American Society for Public Administration, New York

24) Halchin, L. E. (2004). Electronic government: Government capability and terrorist resource. Government

25) Information Quarterly

26) Holmes, D. (2001) eGov: eBusiness Strategies for Government. London, U.K.: Nicholas Brealey

27) IGI Global, What is E-Government, https://www.igi-global.com/dictionary/a-modelproposal-for-local-governments-to-increase-citizen-involvement-in-the-age-ofinformation-society-and-e-government/8704

28) Kafle, S. (2018), What is the difference between e-Government \& e-Governance?,

29) Keohane, R. O. and Nye, J. S. (2000), Introduction, In Nye, J. S. and Donahue, J.D. (editors), Governance in a Globalization World. Washington, D.C.: Brookings Institution Press

30) Kettl, D. F. (2002), The Transformation of Governance, John Hopkins University Press, U.S.A.

31) Key deferences (2017), Difference Between e-Government and e-Governance, https://keydifferences.com/difference-between-e-government-and-e-governance.html

32) Kraemer, K. L., and King, J. L. (2003). Information Technology and Administrative Reform: Will the Time After E-Government Be Different? Paper presented at the Heinrich Reinermann Schrift fest, Post Graduate School of Administration, Speyer, Germany, September 29

33) Lean, O. K., Zailani, S., Ramayah, T., \& Fernando, Y. (2009). Factors influencing intention to use e-government services among citizens in Malaysia. International Journal of Information Management, 29, 458-475. doi: 0.1016/j.ijinfomgt.2009.03.012

34) Leitner, C. (2003), e-Government in Europe: The State of Affairs, European Institute of Public Administration,Maastricht, the Netherlands

35) Marche, S. and J.D. McNiven. (2003), "E-Government and E-Governance: The Future Isn't What It Used To Be", Canadian Journal of Administrative Sciences, 20(1), 2003

36) Margolis, M., Moreno-Riano, G. (2010). E-Government, customers and citizens

37) Marthandan, G. and Tang, C. M. (2010). - Information technology evaluation: Issues and challenges. Journal of Systems and Information Technology, 12(1)

38) Mobile Commerce, Mehdi Khosrow-Pour, Information Resources Management Association, Idea Group Reference, USA

39) Norris, P. (2003). Digital divide - Civic engagement, information poverty, and the Internet worldwide.Cambridge, UK: Cambridge University Press

40) Oakley, K. (2002), "What is e-Governance?", Integrated Project 1: e-Governance Workshop, Strasbourg, 10-11 June, 2002

41) OECD, OECD Glossary of statistical terms https://stats.oecd.org/glossary/detail.asp?ID=4752

42) Okot-Uma, R.W. (2000) Electronic Governance: Re-inventing Good Governance. London, U.K.:

43) Commonwealth Secretaria 
44) ÖKTEM, M. Kemal., DEMIRHAN K. (2004), The Usage of E-Governance Applications by Higher Education Students, EDUCATIONAL SCIENCES: THEORY \& PRACTICE, 2004

45) Organisation for Economic Co-operation and Development. (2001). Citizens as partners. France: Author

46) Palvia, S. and S. Sharma, (2007), "E-Government and E-Governance: Definitions/Domain Framework and Status around the World", Computer Society of India, 2007. Available at: www.csi-sigegov.org/1/1_369.pdf

47) Pina, V., L. Torres and B. Acerté, (2006), "Are ICTs promoting government accountability?: A comparative analysis of e-governance developments in 19 OECS countries". Critical Perspectives on Accounting, 18, 2006

48) Potnis, D. D. (2009). Measuring e-Governance as an innovation in the public sector. Government Information Quarterly, 27, 41-48. doi: 10.1016/j.giq.2009.08.002

49) Prabha, Q.S.V. (2003), Governance: Concepts and case studies, Prentice-Hall, India, 2003

50) Riley, T.B.(2001), "Electronic governance in context". Electronic Governance and Electronic Democracy: Living

51) and Working in the Connected World, The Commonwealth Centre for Electronic Governance, Ottawa, 2001

52) Sanford, C., \& Rose, J. (2007). Characterizing e-Participation. International Journal of Information Management, 27, 406-421. doi: 10.1016/j.ijinfomgt.2007.08.002

53) Sharma, S. K. (2006) An E-Government Services Framework, Encyclopedia of Commerce, E-Government and

54) UN Global E-government Readiness Report. From E-government to E-inclusion, UNPAN/2005/14, United Nations publication, United Nations, 2005

55) Sheridan, W. and T. Riley "Comparing e-Government Vs. e-Governance", GIS Development. (2006). Available at: www.gisdevelopment.net/magazine/years/2006/aug/46_1.htm

56) Signore O., Chesi F. Palloti M. (2005). E-government: challenges and opportunities. CMG itay-XIX Annual Conference

57) Spremić, M., imurina, ., aković, B., and Ivanov, M. (2009), E-Government in Transition Economies. World Academy of Science, Engineering and Technology, Vol. 53. University of Zagreb, Croatia

58) UN, E-Government, https://publicadministration.un.org/egovkb/enus/about/unegovdd-framework

59) Working Group on E-government in the Developing World, (www.pacificcouncil.org)

60) World Bank (2015), e-Government, https://www.worldbank.org/en/topic/digitaldevelopment/brief/e-government

61) Yildiz, M. (2007). E-government research: Reviewing the literature, limitations, and ways forward. Government Information Quarterly, 24, 646-665 